\title{
A maior das maravilhas
}

\author{
ADRIANE DA SILVA DUARTE \\ Departamento de Letras Clássicas e Vernáculas \\ Faculdade de Filosofia, Letras e Ciências Humanas \\ Universidade de São Paulo
}

\begin{abstract}
RESUMO: A análise dos estásimos finais d'As Aves é o ponto de partida para o exame do papel da fantasia na constituição da imagem aristofânica e também para a interpretação dessa comédia como uma critica a Atenas e aos atenienses (e não, como quer Murray, como uma comédia de escape).
\end{abstract}

PAlaVRAS-ChaVE: Aristófanes, comédia ática antiga, teatro, grotesco.

As Aves distingue-se entre as comédias de Aristófanes pelo seu acabamento. O cuidado dispensado à sua confecção fica evidente durante a leitura. A harmonia e o encadeamento do conjunto deixam a impressão de não ter ficado um só ponto sem nó, sensação incomum quando se trata da comédia aristofânica, já que a coerência e a lógica não eram considerados fatores de excelência dramática ou, pelo menos, não tinham o peso que se atribuiu a eles depois.

Comparável aos mais altos momentos da poesia grega, a qualidade de sua lírica também encanta os leitores. Mas aqui não vale o dito que presume ser a qualidade inversamente proporcional à quantidade. As Aves está entre as peças de maior concentração de passagens líricas de Aristớfanes (McEvilley, 1970). A lírica está presente em todas as posiçōes tradicionais ${ }^{1}$, algumas delas duplicadas, e também aparece livre, sob a forma de cantos corais independentes. Há quatro desses cantos corais na peça ${ }^{2}$, um número expressivo quando o padrão é de dois por comédia. São esses cantos o objeto da análise que se segue.

Os estásimos subdividem as cenas episódicas em pequenos atos. Fazendo isso, não só facilitam a compreensāo do público, individualizando e comentando os vários episódios, mas também solucionam um problema técnico. Contando com um máximo de quatro atores para desempenhar inúmeros papéis, o estásimo propicia tempo hábil para as trocas de máscaras e roupas. Então, quanto maior o número de personagens e de cenas pós-parabásicas, maior a quantidade de estásimos em uma peça.

Isso é particularmente verdadeiro no caso d'As Aves, em que há duplicação das cenas episódicas. $O$ aumento no número de cenas corresponde à quantidade elevada de personagens presentes por episódio. Newiger (Newiger, 1975) compara 
As Aves às peças anteriormente compostas e conclui que, enquanto essas últimas apresentam um único grupo de impostores e aproveitadores (alázones), aquela traz à cena dois desses grupos, interessados em tirar vantagem da nova ordem estabelecida pelo herói. As outras comédias apresentam cerca de dois componentes por grupo, enquanto nesta a variação é de três a cinco elementos. Além das duas cenas com impostores mortais, $A s$ Aves tem também três cenas com deuses: prisão e interrogatório da deusa fris, visita de Prometeu e embaixada de Poseidon, Héracles e Tribalo. $O$ número de estásimos, quatro, é o dobro do habitual em resposta à extensão anormal dos episódios.

Muitas vezes os estásimos parecem desvinculados do tema principal da comédia. Essa impressão deriva do uso de imagens complexas e altamente concentradas, o que, associado à menção a fatos e personalidades contemporâneos do poeta, pode desnortear os leitores de hoje. No entanto, uma análise interpretativa dos estásimos é capaz de resgatar plenamente seu sentido face à obra. No que diz respeito Às Aves, os estásimos I e II inserem-se bem no contexto, uma vez que limitam-se ao comentário de cenas vizinhas; já os estásimos III e IV exigem maior atenção, por seu caráter de sátira direta a indivíduos históricos, que não faziam parte do enredo da peça. Por isso, concentrarei o comentário sobre esses últimos, que reproduzo a seguir em tradução própria.

Estásimo III (v. 1470-93)

Muitas novidades e maravilhas

já sobrevoamos

e fatos assombrosos vimos.

Há uma árvore, de natureza estranha, pra lá de Briosa: Cleônimo,

bom para nada e, aliás,

covarde e muito.

Ela, na primavera, desabrocha e delata;

no inverno, em compensação,

deixa cair seus escudos.

Há também uma terra junto à Escuridāo, lá. longe, no Ermo de Lamparinas.

Lá, homens com heróis

almoçam e convivem,

exceto ao entardecer.

Nessas horas encontrá-los

não era seguro mais.

Se algum mortal topava

à noite com Orestes, o herói,

ficava nu, depois de ser surrado

em todo o seu flanco direito.

Estásimo IV (v. 1553-64; 1694-1705)

Junto aos Pés-Sombreiros

existe um lago, onde, sem se lavar,

Sócrates atrai as almas. 
Ali também veio Pisandro, pedindo para ver uma alma, que o abandonou ainda vivo.

Segurando uma vítima, um camelo-ovelha, cortou-lhe a goela e,

como Odisseu, recuou.

Em seguida surgiu-lhe de baixo, rumo à sangoela do camelo, Querofonte, o morcego.

Existe em Delação, junto à Tribuna, uma raça velhaca de ventrelinguarudos, que semeiam, colhem e vindimam com as línguas, e também dão com a língua nos dentes. ${ }^{3}$ São de raça estrangeira, os górgias e os felipes.

Por causa daqueles ventre-

linguarudos felipes, em toda a Ática, nos sacrifícios, a língua é cortada e posta à parte.

Os estásimos III e IV estão estreitamente vinculados. Em primeiro lugar transparece um paralelismo formal: ambos contam com 24 versos cada, divididos em duas estrofes de 12 versos, enquanto os estásimos I e II contam com 14 e 8 versos respectivamente, também distribuídos em duas estrofes simétricas $(7 / 7 \mathrm{e}$ 4/4). O metro também aproxima os estásimos III e IV, já que ambos empregam trocaicos, e os distingue dos anteriores, que foram compostos em jambos e docmíacos à vez.

Também pode-se notar que os estásimos I e II se inserem num contexto predominantemente humano (sacrifício de fundação da cidade, primeira procissão de aproveitadores, chegada do mensageiro dos homens), enquanto os estásimos III e IV estão entre as cenas em que domina o divino (Prometeu e a embaixada dos deuses). E verdade que entre a estrofe e a antístrofe do estásimo II há o interrogatório da deusa Iris, que antecipa a participação divina. Mas são os aproveitadores humanos que dão o tom à passagem com sua presença insistente (o primeiro grupo traz cinco elementos que relutam em deixar a cena).

No estásimo III sāo contíguas estrofe e antístrofe, produzindo um canto de maior duração (24 versos contínuos para 12 de cada estrofe do IV, 7 do I e 4 do II). A principal razão disso, ao meu ver, é enfatizar o fim da participação humana e marcar o início da presença divina. Antecede a esse estásimo a segunda procissão de aproveitadores (parricida, Cinésias, delator) e o segue a visita de Prometeu e a embaixada dos deuses.

Os estásimos III e IV também estão ligados tematicamente. O tema que neles predomina é introduzido logo nos primeiros versos do terceiro estásimo (v. 1470-72):

polld de kal kaind kai thau-

mást' epeptómestha, kat

deina prágmat' édomen. 


\section{Muitas novidades e maravilhas \\ já sobrevoamos e \\ fatos assombrosos vimos.}

Trata-se do tópos do viajante, aventureiro desbravador de terras distantes. $\mathrm{O}$ tema adequa-se bem ao coro de aves, composto por muitas migrantes sazonais. Mas detalhes de ornitólogo são dispensáveis, bastando mencionar a grande imagem das asas, eternamente associadas à mobilidade, à liberdade de ir e vir, de cruzar fronteiras (Chevalier e Gheerband, 1973, p. 28-30). Asas são metáforas gregas para as velas, que transportaram os colonizadores atenienses por mar. Por mar também as primeiras e maiores aventuras se fizeram, a expediçāo dos Argonautas e a Odisséia.

O viajante e o narrador são lados da mesma moeda: "Quando alguém faz uma viagem, então tem alguma coisa para contar, diz a voz do povo e imagina o narrador como alguém que vem de longe" (Benjamin, 1983, p.58). Para Walter Benjamin, os primeiros narradores, detentores da experiência comunicável, foram - lavrador sedentário, conhecedor das tradiçōes locais, e o marinheiro mercante, que traz as novidades do além mar. Do primeiro tipo é representante Hesíodo, do segundo, Odisseu de Homero e Heródoto.

As aves pertencem ao segundo tịpo, são narradoras das novidades. Há uma longa tradição de aves mensageiras, cuja função abrange a previsão do tempo (p. ex. As Aves, v. 699 sq.) ou o anúncio das intençōes divinas (As Aves, v. 719) - o termo grego para ave também significa augúrio. $O$ uso de pássaros como correio reflete-se nos ditados populares "um passarinho me contou" e "ver um passarinho verde", de abrangência universal e difundidos ainda hoje ${ }^{4}$.

No estásimo III as aves propõem-se a relatar as novidades (kainá), maravilhas (thaumastá) e fatos assombrosos (deiná prágmata). O leitor de Heródoto vai se sentir à vontade. Desde a análise de François Hartog (Hartog, 1980, p.243-49) sabe-se da importância do thaúma na organização do discurso etnográfico do historiador. Em Heródoto o thaúma é, por definição, algo assombroso (deiná) ou desconhecido (kainá).

Vale lembrar também o registro épico da palavra, sempre associada à intervenção milagrosa da divindade, como nesta passagem da Odisséia (XIX, 36):

ó páter, 'é méga thaúma tód' ofthalmoísin horómai.

Pai, esta grande maravilha certamente com os meus olhos vejo! $!^{5}$

em que Telêmaco dirige-se a Odisseu para descrever os indícios da presença de Atena. Embora o Ciclope, os Lotófagos, Cila e Caríbdis não sejam seres comuns, e de fato nenhum deles compōe a paisagem doméstica de ftaca, Odisseu não se refere a eles como maravilhas. O maravilhoso restringe-se ao âmbito dos deuses.

Em Heródoto o thaúma deixa de constituir um sinal de epifania para se transformar em uma categoria do discurso etnográfico, responsável não só pela organização do lógos, mas também pela veracidade do relato do historiador. Segundo Hartog (Hartog, 1980, p.243-49), as maravilhas-curiosidades são requisitos indispensáveis à apreensão de outras culturas, relacionando-se à descoberta do outro pelo contraste com o eu, à questão da identidade. Em Homero, o mortal confronta-se com o imortal, mas também, como em Heródoto, o grego com o 
bárbaro. A alteridade e, em conseqüência, a identidade, são sublinhadas pelo thaúma, que pode ter origem humana (monumentos, costumes) ou natural (fauna, flora, anomalias climáticas). Por este motivo o thaúma sempre pertenceu ao universo dos viajantes e dos exploradores. E, sendo assim, nāo poderia faltar à narrativa das aves.

Ainda no campo das palavras, Hofmann (Hofmann, 1976) e Moulton (Moulton, 1981) percebem nos versos iniciais desse estásimo III um eco do famoso canto coral da Antigone de Sófocles (v. 335-75), que principia assim:

pollà tà deind koudèn anthrópou deinótéron pélei.

Muitas são as coisas assombrosas, mas nada é mais assombroso que o homem.

Também aqui se destaca a palavra deiná que, juntamente com thaúma, caracteriza a visão das aves. $O$ parentesco entre os estásimos de Aristófanes e de Sófocles vai além do vocabular. Os versos d'As Aves não tardarão a confirmar que o homem é o que há de mais assombroso (deinóteron) sobre a terra. Mas enquanto Sófocles enuncia e enumera o que existe de assombroso no ser humano, Aristófanes o sugere através de imagens.

A investigação do processo de formação e encadeamento das imagens dos estásimos III e IV, uma amostra do que ocorre no restante da peça, levará à abordagem do papel da fantasia na obra de Aristófanes, mas não no sentido comum da palavra, i. é, imaginação desenfreada, devaneios desligados da realidade. Aqui deve-se entender fantasia como uma estrutura mental responsável pela criação poética, espaço paralelo à realidade, mas nunca apartado dela. De acordo com Whitman (Whitman, 1964, p.260-61) "a fantasia aristofânica é uma estrutura [...] que desperta a reação da mais básica função mental: a transformação da corrente caótica da experiência em uma seqüência de agrupamentos inteligíveis. [...] a mente primeiro forma classes e lhes dá nomes; os nomes estimulam o processo através de sua própria propensão à conotação, combinação e ambigüidade. Por esse processo o mundo inteligivel alça-se a alturas imaginativas espantosas, que poderiam não ser significativas se não fosse o fato de que a amplificação verbal, poética, da realidade é paralela e parte da formação mental da realidade mesma. [...] $\mathrm{E}$ devemos supor que estruturas poéticas são, de qualquer modo, significativas." Essa definição norteará a análise das imagens dos estásimos III e IV.

Nas estrofes que compõem os estásimos III e IV são apresentados quatro exemplos das maravilhas vistas pelas aves: 1) árvore-Cleônimo (v. 1470-81); 2) herói-bandido Orestes (v. 1482-93); 3) Sócrates e Pisandro no Hades (v. 1553-64); 4) ventrelinguarudos Górgias e Felipe (v. 1694- 1705). Todas partilham a introdução ("existe em tal lugar, tal coisa") que as situa geograficamente num ponto remoto do mapa, em terras de difícil acesso ou em regiōes míticas, mas, de qualquer forma, distantes de Atenas.

A árvore-Cleônimo, primeira das maravilhas, situa-se "longe de Briosa" (em grego, Kardía), cidade da desconhecida Trácia. E, sem dúvida, a imagem mais bem trabalhada e mais rica em significados, muitos deles já apontados por Taillardat (Taillardat, 1965, 726 e 896).

Essa é uma imagem de cunho essencialmente grotesco, onde se tem, em primeiro plano, a fusão entre o homem e o vegetal. Em contraposiçāo à estética clássica que elege o contorno claro, delineador das formas, preservador da indi- 
vidualidade e da identificaçāo, a grotesca promove a dissolução de linhas e a fusāo entre as formas, como entre as espécies, colocando elementos diversos em contato. A concepçāo grotesca leva à constituiçāo de um corpo híbridó e está no cerne das fantasias anatômicas, responsáveis por boa parte do fabulário folclórico. Além disso, o corpo híbrido, segundo Bakhtin (Bakhtin, 1987, p.245), consolida o "encontro entre o homem e o mundo", já que o aproxima de elementos de origem variadas.

Nesse contexto insere-se a árvore-Cleônimo. Note-se que essa imagem de cunho fantástico (não existem seres meio homens, meio plantas) tem como núcleo um indivíduo empírico, nomeado e reconhecível. Cleônimo foi um político ateniense de pouca expressão, somente lembrado por ter sido uma das vítimas preferenciais de Aristófanes que, em várias oportunidades, satirizou-lhe a obesidade, a glutonaria, a covardia, o caráter traiçoeiro (p. ex. As Aves, v. 288-290). Nesse estásimo d'As Aves dois de seus defeitos são ressaltados: covardia e caráter traiçoeiro, evidente já no hábito que cultivava, a delação. Talvez sua obesidade seja também aludida, como acredita Taillardat (Taillardat, 1965, 425), mas não com a mesma ênfase dos defeitos anteriormente mencionados, o que permite ignorá-la.

A árvore-Cleônimo conjuga atividades humanas e vegetais: desabrochar, mostrar figos/delatar, perder folhas/perder escudos. Predominam traços do reino vegetal, já que o verbo sukofantein significa literalmente "mostrar figos" (i.é, frutificar) e só figuradamente "delatar" e fullorroein quer dizer "perder as folhas", a idéia de "perder os escudos" só é obtida pela imposição do objeto direto aspídas (escudos) ao verbo, intransitivo.

Dessa perspectiva percebe-se que o fator determinante na formação da imagem é a livre associação de idéias, em que atuam dois elementos poderosos: 1) concretização de conceitos ou literalização de expressões, 2) encadeamento de palavras, ordenadas pelo campo semântico a que pertencem (palavra-puxa-palavra).

Cleônimo é sicofanta, que habitualmente significa delator. Aristófanes entende a palavra ao pé-da-letra e, em seguida, a concretiza e contextualiza: sicofanta = mostrador de figos, figo (sýkon), figueira (suké), árvore (déndron). Daí a imagem da árvore-Cleônimo, naturalmente uma figueira.

E esse caminho tem mão-dupla na medida em que um objeto concreto, assim reconhecível pelo contexto, pode ser tomado em seu sentido figurado. Assim se explica o "bom para nada" (literalmente do grego chrésimos oudén, v. 1476), que substitui o adjetivo sýkinos, referente à figueira e, figuradamente, ao que é mole e imprestável como o tronco da figueira, que não serve para nada. Portanto a livre associação de idéias conduz à formação de uma imagem grotesca que joga com inúmeras variáveis previsíveis logicamente.

Outro motivo de interesse nessa imagem é a relação que se estabelece entre ela e a sua coordenada geográfica. A árvore-Cleônimo fica longe de Briosa, que, como já foi adiantado, é uma localidade da inexplorada Trácia. Naturalmente, dentro do esquema de afastamento da civilizada Atenas, pode-se entender a localização como uma tentativa de situar a maravilha em terras desertas ou bárbaras. Mas parece que foi o nome da cidade, mais do que a sua posição geográfica, que determinou a escolha do poeta. O nome grego Kardía significa coração e evoca coragem, brio, como indica a tradução por Briosa. Assim, opõe-se a "covarde e muito" (v. 1476): a árvore-Cleônimo fica longe de Briosa (Kardía) e é muito covarde. 
Além de explorar o valor geográfico e semântico do termo, apresentar Kardía como uma cidade permitiu a Aristófanes manter a ambigüidade do termo éktopos (v. 1474) que quer dizer estranho, mas também estrangeiro (literalmente: o que está fora de lugar). A escolha da cidade pelo seu sentido e localização, assim como a do substantivo enquanto topônimo, responde à trama semântica que está na raiz dessa imagem: um covarde em Kardía é um estrangeiro.

Há ainda o cruzamento da deilía (covardia) de Cleônimo com o fato curioso da árvore perder seus escudos no inverno, referência a ato semelhante do homem em uma batalha. Completa-se a imagem e o retrato de Cleônimo: covarde, alcagüete e imprestável. Nada se perde, cada palavra é aproveitada nessa caracterização, prova da inexistência da fantasia desenfreada, saída do nada, em Aristófanes. A fantasia aristofânica é derivada da livre associação de idéias, que parte sempre de um núcleo concreto, identificável, com como e com porquê.

Bem mais simples que a anterior, a segunda imagem apóia-se sobre uma homonímia. $O$ nome Orestes designa tanto o herói trágico, filho de Agamenão e Clitemnestra, quanto um arruaceiro, ladrão de roupas, atuante na Atenas de Aristófanes. Joga-se com a sobreposição entre as duas personagens, o herói e o bandido.

Essa degradação do elemento mitológico através da fusão de um herói com um mero mortal, e ainda ladrão, é o traço mais visível do grotesco nessa estrofe. Toda vez que a ênfase recai na paródia do mito ou da literatura, o uso de elementos grotescos puros $\varepsilon$ deslocado para o segundo plano, dos protagonistas para as pessoas ou coisas que os cercam (ver a estrofe do estásimo IV). Isso porque o recurso à paródia, em si, já está no âmbito do grotesco ao promover o rebaixamento do que é nobre e sério, tornando-o vulgar e festivo.

O Orestes apresentado por Aristófanes não é o jovem atormentado que deve vingar na mãe a morte do pai, mas o perseguido pelas Erínias vingadoras do sangue parental, vítima de delírios constantes, que podem torná-lo violento. A violência é um predicado dos dois Orestes, pois os métodos do ladrão de roupas incluíam um nocaute que facilitaria o desnudamento da vítima (p. ex. As Aves, v. 493-98).

Mas o perigo vem com a noite, com a escuridão. Período preferencial para o ataque dos bandidos e para a aparição das assombraçōes, das quais faziam parte os heróis. Uma crença popular estabelecia que o mortal que visse um herói seria tomado de estupor, ficando paralisado temporariamente, como se tivesse visto um fantasma.

A localização geográfica é adequada a esses seres noturnos. Eles habitam uma terra situada (v. 1482-84):

\section{[...] pròs autói, tói skótoi pórro tis en téi lýkhnon eremiai. \\ ...junto à Escuridão, lá longe, no Ermo de Lamparinas.}

Em grego há um trocadilho entre líkhnon eremía (Ermo de Lamparinas) e Skuthón eremía (deserto Cita), que é uma região selvagem e desabitada. Carroll Moulton (Moulton, 1981) nota que nesse deserto fica aprisionado o Prometeu de Ésquilo (Prometeu Acorrentado, v. 2). Sua alusão aqui prenunciaria a entrada de Prometeu em cena, que ocorre logo após esse estásimo. Essa leitura pode parecer um pouco forçada, especialmente para os descrentes do poder da sugestão sonora no âmbito de uma cultura predominantemente oral. Mas não se deve deixar de notar 
que, nesse estásimo III, a estrofe, que trata do sicofanta Cleônimo, é antecedida da procissão de aproveitadores humanos, assim como a antístrofe, que trata do herói Orestes, é seguida da visita do Titã Prometeu. Isso indica que esse estásimo realiza a transição das cenas em que predominam seres humanos para as comandadas por deuses, o que já foi mencionado antes ao se comentar a razão da maior extensão desse canto, que apresenta estrofe e antístrofe contíguas.

Após a cena com Prometeu, segue-se a estrofe do estásimo IV. Como a antístrofe do estásimo III, esta estrofe também está centrada na paródia mitológica. Nela é parodiada a nekuía (descida ao Hades) de Odisseu no canto XI da Odisséia. Só que na comédia quem tem sua nekuía é o político demagogo Pisandro que, ainda vivo, procura sua própria alma. Como nota Ruck (Wasson, 1992), o tema do sacrifício, presente nesse estásimo, está diretamente ligado à visita de Prometeu, que o instituíra como um vínculo entre deuses e homens (As Aves, v. 1546).

Novamente a presença da paródia produz um deslocamento dos elementos grotescos puros que, nem por isso, desaparecem. Grotesca é a vítima que Pisandro sacrifica aos mortos: um camelo-ovelha, animal híbrido, fabuloso, adequado às terras longínquas e concorde com a concepção grotesca do corpo.

Também faz parte da estética do grotesco o acoplamento de palavras na criação de neologismos através de processo similar ao usado na composição da imagem grotesca: a fusão.eliminadora de contornos. Exemplo disso é a palavra laíma (v. 1563). A sua tradução por "sangoela" evidencia a derivação de laimós, garganta e haíma, sangue. Com exceção do dicionário Bailly, que registra a palavra como um neologismo cômico, comentadores recusam-se a ver nela qualquer sentido, apostando em um erro de copista ${ }^{6}$. Mas um dos comentadores máis habilitados de Aristófanes, Kock (Kock, 1876, p.229), recusa a explicação corrente, até porque todos os manuscritos atestam a mesma forma ${ }^{7}$. E do ponto de vista do grotesco realmente não há erro.

Outra imagem acessória apresentada sob a ótica grotesca é a de Querofonte-morcego (v. 1564). O morcego foi escolhido por sua atração por sangue, pelo par de asas - na antigüidade era classificado entre as aves -, e pela atividade noturna, como o nome grego sugere: nykteris de nýx, noite. A escolha de Querofonte foi determinada pela presença de Sócrates, seu mestre, na mesma estrofe (v. 1555), assim como por sua fama de morto-vivo, muito adequada ao Hades.

O Hades de Pisandro situa-se junto aos Pés-Sombreiros (Skiápodes), povo fabuloso que utilizaria seus grandes pés como guarda-sol. Sua menção aqui talvez se deva a Prometeu, que poucos versos acima utiliza-se de um guarda-sol para escapar ao olhar vigilante de Zeus. Os elementos componentes do nome desse povo, skiá, sombra e poús, pé, dominam a estrofe: as trevas que envolvem esse Hades, pressupostas pela presença do morcego; o movimento de ir e vir, enfatizado pelo triplo emprego do verbo érchomai, ir (v. 1556, 1561, 1562, com diferentes prefixos). Além disso, Pés-Sombreiros também pode ser entendido como pés-sujos, justamente uma das características de Sócrates, que é satirizado na seqüência. Para obter tal efeito, Aristófanes usa um processo semelhante ao da estrofe do estásimo III, quando, partindo do termo sicofanta, concretiza os elementos que o compõem, dando-lhes vida própria, de modo que passam a atrair palavras pertencentes ao seu campo semântico ou idéias pertinentes a ele.

Também a covardia é um elo entre essa estrofe e a do estásimo III, o que nâo é de se admirar quando um Prometeu medroso acaba de sair de cena. Lá o covarde era Cleônimo, que perde seu escudo, aqui é Pisandro, que procura sua 
própria alma. A palavra alma, psyché, também significa coragem em grego. Através do sacrifício de uma vítima, Pisandro, imitando Odisseu, busca recuperar sua alma/coragem, mas tudo o que consegue é Querofonte-morcego.

Além de Pisandro, nessa estrofe também Sócrates está interessado em almas, mas de forma diferente. Ele conduz ou seduz almas, ambigüidade mantida pelo verbo psychagogein. $O$ verbo indica tanto a habilidade socrática de encantar o ouvinte pelo discurso, quanto seu efeito sobre a aparência de seus discípulos. Os jovens, voltados mais para os exercícios do espírito do que do corpo, privam-se das atividades ao ar livre e adquirem uma palidez cadavérica, assemelhando-se aos mortos. Sócrates, à maneira de Caronte ou Hermes, guiaria esses mortos-vivos até o Hades sombrio, i.é, sem sol. O estereótipo do discípulo socrático na comédia antiga é Querofonte (v. 1564), descrito como assustador pelo mesmo Aristófanes n'As Nuvens (v.102-04).

Outro alvo de sátira nessa estrofe é o proverbial desleixo socrático com a própria aparência. Mesmo estando junto a um lago (v. 1554), o filósofo resiste à tentação de um banho, o que reforça o sentido figurado de Pés-Sombreiros como pés-sujos.

A antístrofe do estásimo IV é a mais bem amarrada com as outras. $O$ ataque aos sofistas ("Sócrates", Górgias e Felipe) e o contexto sacrificial (imolação do camelo-ovelha e corte e separação da língua) aproximam-na da sua estrofe. A crítica aos delatores (Cleônimo, Felipe) a liga à estrofe do estásimo III.

Carroll Moulton (Moulton, 1981) aponta a importância da língua na composição dessa estrofe. Seguindo-se à embaixada dos deuses, ela não poderia deixar de destacar o poder da língua, símbolo do discurso persuasório com que Pisetero (literalmente, o companheiro persuasor, Bom de Lábia) obtém Soberania em casamento. Realmente a língua constitui o núcleo desse canto coral, fazendo-se presente por toda a parte, especialmente na caracterização dos seres fantásticos ali descritos, os ventrelinguarudos (egglottogástor).

Neologismo formado por analogia a egcheirogástor (o que obtém seu sustento com as mãos), a palavra é resultado da aglutinação de glótta, língua e de gáster, ventre. A imagem derivada é de gosto grotesco. $O$ corpo esquartejado tem partes suas destacadas e é remontado ao bel-prazer do autor numa fantasia anatômica que só obedece às necessidades fisiológicas básicas: comer e procriar - o maior sinal da gravidez é justamente o inchaço do ventre. Acoplados, ventre e língua dāo origem a um ser, concreto, que tem como função exclusiva o comer e o falar, ou o comer mediado pelo falar (egglottogástor, o que obtém o seu sustento com a língua). A imagem aplica-se aos sofistas Górgias e Felipe, que supostamente viviam dos seus ensinamentos, i.é, da sua língua.

O corpo esquartejado é signo não só do grotesco, mas também do sacrifício. $O$ ato ritual de cortar e separar a língua das vítimas, autonomizando-a, é interpretado pelo coro como símbolo da persuasão pela palavra, que em Atenas está associada aos sofistas. Além disso, por serem na sua maioria estrangeiros, os sofistas são classificados como bárbaros. Palavra onomatopaica que descreve o balbuciar ininteligível do estrangeiro, do que não fala grego, bárbaro designa um engrolar de língua que inviabiliza a comunicação. Ou seja, para Aristófanes, a idéia de língua é indissociável dos sofistas.

Outra forma de se obter o sustento com a língua é a delação. Esse tema já havia sido abordado na estrofe do estásimo III através da imagem da árvore-Cleônimo, que "mostrava os figos" (sykofantel) na primavera. Nessa antístrofe o processo 
de formação da imagem é aproximado. O adjetivo panoúrgos (v. 1695) tem duplo sentido. Literalmente significa o que é capaz de fazer tudo, cujo valor positivo corresponde a ativo, industrioso e o pejorativo a velhaco, patife. Seguem-se a ele três verbos coordenados que designam atividades agrícolas: colher (therizo), semear (speíro) e fazer a vindima (trygáo). Nesse contexto é natural eleger o sentido positivo do adjetivo, que se adequa perfeitamente à idéia de egcheirogástor, presente subliminarmente. O que desmonta, ou remonta, a interpretação é o acréscimo de um quarto verbo, colher figos (sykázo), que, associado ao tema principal, a língua, vincula-se definitivamente a sicofanta, por pertencer ao mesmo campo semântico de sýkon (figo), explorado antes.

Os ventrelinguarudos habitam Fanas/Delação (Fánai), cidade da ilha de Quios, aliada dos atenienses. A escolha dessa localidade obedece um critério análogo ao de Briosa/Cardia na estrofe do estásimo III. Cardia foi escolhida principalmente devido ao seu significado (brio), assim também Fanas. Da mesma raiz do verno faíno (mostrar, revelar, delatar), componente de sicofanta e sykofantéo (v. 1479), Fanas quer dizer delação. Portanto o habitat antecipa o caráter de seus habitantes.

O fato de dessa vez tratar-se de um lugar que está no mapa e, mais do que isso, de uma cidade aliada é significativo. Das quatro estrofes que foram aqui examinadas essa é a única que tem uma localização acessível e civilizada. $O$ contexto, reconhecidamente grego, torna-se ateniense com a menção à clepsidrá (v. 1695), o relógio de água que marcava o tempo dos oradores na ágora ${ }^{8}$. Dessa forma, não é de se estranhar que a Ática apareça no penúltimo verso (v. 1704).

Interrompe-se nessa antístrofe o procedimento de situar os seres fantásticos em terras remotas e fabulosas. Eles habitam o mundo grego, estão nas praças de Atenas. E isso vale não só para os ventrelinguarudos, mas também para todos os anteriores. Os estásimos confirmam, à sua maneira, os versos de Sófocles: "muitas são as coisas assombrosas, mas nada é mais assombroso que o homem". Afinal, quem são os seres fantásticos? Cleônimo, Orestes, Sócrates, Pisandro, Querofonte, Górgias e Felipe. Todos figuras familiares aos atenienses e que poderiam, inclusive, estar sentadas ali no teatro, ouvindo esse coro cantar.

$A$ interligação entre as estrofes e entre os estásimos foi demonstrada e foram indicados alguns traços que os integram ao contexto imediato em que se inserem, i.é, as cenas episódicas. Resta agora relacionar esses éstásimos à comédia como um todo.

Cardia/Briosa na Trácia desconhecida, a deserta Citía, o lago dos Pés-Sombreiros $^{9}$ e Fanas/Delação: as terras distantes, não menos que seus habitantes, revelam Atenas. Partindo disso, pode-se imaginar ainda um outro estásimo que, embora nunca tenha sido escrito, faz-se sentir por toda a peça. Este estásimo imaginário, caso tivesse sido composto, começaria assim:

Lá no céu, entre às nuvens,

fica Cuconuvolândia, onde Cuco-Pisetero, com a língua,

mandou erguer um muro

para combater os deuses...

Como na maioria das estrofes antes examinadas, também o grotesco predomina na figura de Pisetero, meio homem, meio pássaro. Na peça ele se transforma efetivamente em ave após ingerir certas raízes oferecidas por Tereu (As Aves, v. 655), embora sua aparência deixe muito a desejar. 
Também o nome da localidade antecipa ou determina as qualidades dos seus moradores. Cuconuvolândia, nome pomposo da cidade das aves, é formado da junção de neféle, nuvem e $k \delta k k y x$, cuco. Nuvem remete ao céu, espaço por excelência dos pássaros. A nova cidade, situada entre o céu, a terra e o éter, paira no ar como as aves que a habitam. Ao mesmo tempo, a nuvem, composto de água e ar, aponta para o caráter impalpável da cidade que, feita de névoa, é nada.

Cuco é referência a Pisetero, homem-pássaro que usurpou a Soberania aos herdeiros legítimos, as aves. Agindo assim, ele se comporta exatamente como o cuco que, nascido no ninho de outros pássaros, chocado e alimentado por pais adotivos, retribui esses cuidados matando os filhotes verdadeiros para não ter que dividir com eles a comida. Pollard (Pollard, 1977, p.44), em seu livro sobre as aves na vida e no mito gregos, atesta que esse mau costume dos cucos já era largamente conhecido pelos antigos.

Pisetero é um ateniense e Cuconuvolândia um reflexo de Atenas. A cidade aérea reproduz Atenas por ser esse o modelo de cidade que seus fundadores, Pisetero e Evélpides, conhecem. Se eles, aparentemente, rejeitam delatores e sofistas - uma investigação sobre o caráter de Pisetero deixaria muita pulga atrás da orelha -, adotam métodos imperialistas de conquista. Afinal, o primeiro ato de Pisetero é murar a cidade e promover um cerco aos deuses, tática similar às empregadas por Atenas e Esparta contra os inimigos durante a Guerra do Peloponeso e cujo exemplo mais significativo é o sítio à ilha de Melos. Ocorrido no ano anterior à encenação d'As Aves, o episódio impressionou vivamente toda a Hélade por seu desfecho violento: o massacre de ilheús neutros que se recusavam a apoiar Atenas. Mas Melos é apenas um caso, o extremo, em uma longa série que Pisetero parece ter assimilado bem.

De todos os locais arrolados nos estásimos Cuconuvolândia é o mais maravilhoso $^{10}$, assim como o homem-pássaro Pisetero, que desbanca os deuses, é a maior das maravilhas. Através da análise do texto isso fica claro, o que não acontece quando se opta por uma leitura da obra que encare os estásimos como detalhes ou os separe do contexto. Lugar comum entre os helenistas, reforçado pela solidez intelectual e pelo estilo encantador de Murray (Murray, 1933), é considerar As Aves uma comédia de escape, voltada para o reino da fantasia e totalmente desvinculada da vida real. Essa linha de raciocínio deriva na interpretação da peça como expressão de uma utopia, o reencontro entre o homem e a natureza, ou a idealização da cidade perfeita, que nada teria da pervertida Atenas do sec. V (!). Mas o fato é que a presença de Atenas é fortemente sentida durante toda a obra, nos atos e nas palavras de Pisetero, na procissão de aproveitadores que assola a recém fundada cidade celeste. Nunca Atenas esteve mais presente em uma comédia de Aristófanes. Só que, como nos estásimos analisados, ela está disfarçada. Atenas é Cuconuvolândia, Briosa, o Ermo de Lamparinas, o Hades dos Pés-Sombreiros, Delação. É esse o segredo revelado no canto dos pássaros.

Recusar a visão da comédia de escape não equivale a admitir que, no caso d'As Aves, trate-se de um roman a clefs, em que Pisetero seria Alcebíades, o Olimpo representaria o Peloponeso, as aves os atenienses e assim por diante ${ }^{11}$. Essa interpretação é demasiado mecanicista e, na ânsia de provar os vínculos da comédia aristofânica com a realidade, termina por negar o lugar privilegiado da fantasia no processo de criação do poeta, como se a obra fosse um retrato fiel da vida. Atenas é a chave da comédia, sim, mas não há charada a matar. O diálogo entre poesia e sociedade, norma no teatro grego, não cabe numa fórmula rígida. 
A fantasia tem grande importância nessa comédia. Mas, como ficou demostrado através da análise das imagens dos estásimos, pode-se concluir que fantasia para Aristófanes assume um sentido muito diferente do senso comum. Toda a imagem tem um núcleo concreto e reconhecível a partir do qual se desenvolve em múltiplas direções, aproveitando as coincidências sonoras, as ambigüidades semânticas, etc. Esse processo associativo, que pode resultar em algo tão absurdo como uma cidade nas nuvens ou em seres ventrelinguarudos, é perfeitamente lógico, podendo-se recuperar cada etapa do raciocínio que os gerou - como comprova a análise dos estásimos III e IV.

A fantasia que predomina n'As Aves é regida pela imaginação grotesca. Bakhtin, referindo-se a Rabelais (Bakhtin, 1987), notou que o predomínio do grotesco inibe a presença da sátira direta - embora não a suprima -, o que é um motivo para Atenas vestir a máscara nessa comédia. Mas por trás da máscara seu rosto deixa-se ver por momentos, como quando se percebe que a maior das maravilhas nāo é o homem em geral, mas, sim, o ateniense.

\section{Notas}

1- As posiçōes tradicionais são párodo, agón, parábase e êxodo.

2- I) $851-857$, 895-901; II) $1189-1195$, 1262-1266; III) 1470-1481, 1492-1493; IV) 1553-1564, 1694-1705.

3- Literalmente: "e com elas também apanham figos".

4- Cf. Cascudo, 1986, p.195: "Viu passarinho verde? - Denúncia de novidade feliz, ventura, alegria. [...] O passarinho verde representará o psitacídeo, falante e secularmente mensageiro de amores, levando no bico dourado a carta da namorada".

5- Todas as traduções sằo de responsabilidade da autora.

6- Cf. Sommerstein (Aristophanes, 1987) que o aproxima do verbo laíein, degolar; Casevitz (Casevitz, 1978) que chega a pensar em neologismo, mas prefere a correção para léma, coragem; Cantarella (Aristofane, 1949) que emenda o manuscrito para lémma, pele.

7- Embora Kock não defenda a idéia de neologismo, também não corrige o seu texto: "v. 1563 - laima ist kein Wort [...]. Es fehlt bis jetzt genuegenden Verbesserung und Erklaerung der Stelle".

8- A tradução por Tribuna visa associar imediatamente o delator ao orador profissional, o sofista.

9- Ruck (Wasson, 1992) localiza o lago como o pântano das Lenéias, onde haveria um teatro e um templo de Dioniso. Lá seria o cenário das Antestérias, festa de celebração dos mortos e por isso é visto por Aristófanes como uma entrada do Hades. $O$ restante da análise, que supõe ser o estásimo IV uma sátira à recente profanação dos Mistérios e que identifica os Pés-Sombreiros com um tipo de cogumelo alucinógeno, pareceu-me um tanto forçada.

10- Devo a Whitman (Whitman, 1964, p.194) a percepção de Cuconuvolândia como "a maior das maravilhas geográficas". 
11- Para uma visão d'As Aves como roman à clefs, Arrowsmith (Arrowsmith, 1973) e Katz (Katz, 1976) apud Thierçy (Thierçy, 1986, p.198, n.22); como utopia, Reckford (Reckford, 1987) e Rodrigues (Cardoso, org., 1991, p.50-56).

\section{Referências Bibliográficas}

ARISTOFANE. Gli Ucelli (Le Comedie IV). Edição e notas de R. Cantarella. Milano: [s. ed.], 1949.

ARISTOPHANES. Birds. Edição e comentários de Alan Sommerstein. Whiltshire: Aris \& Phillips, 1987.

BAKHTIN, Mikhail. A cultura popular na Idade Média e no Renascimento (O contexto de Rabelais). Tradução por Iumna Maria Simon. São Paulo: Hucitec/UNB, 1987.

BENJAMIN, Walter. O narrador. In: Benjamin, Habermas, Horkheimer e Adorno. Textos escolhidos (Os Pensadores). Tradução por Modesto Carone. São Paulo: Ed. Abril, 1983, p.57-74.

CASCUDO, Câmara. Viu passarinho verde? In: - . Locuçōes tradicionais do Brasil (Coisas que o povo diz). Belo Horizonte: Itatiaia/EDUSP, 1986, p.195.

CASEVITZ, Michel. Commentaire des Oiseaux d'Aristophane. Lyon: L'Hermes, 1978.

CHEVALIER e GHEERBAND. Ailes. In: - . Dictionnaire des symboles. Paris, 1973, p. 28-30.

HARTOG, François. Une rhétorique de l'alterité: la mesure du thôma. In: - . Le mirroir d'Herodote (Essai sur la representation de l'autre). Paris: Gallimard, 1980, p.243-249.

HOFMANN, Heine. Mythos und Komödie. Hildesheim: Georg Olms, 1976.

KOCK, Theodor. Ausgewählte Komödien des Aristophanes (v.IV). Berlin: Weidmannsche Buchandlung, 1876.

McEVILLEY, T. Development in the lirics of Aristophanes. American Joumal of Philology, Baltimore, v.91, n.4, p. 257-276.

MOULTON, Carroll. The liric of insult and abuse. In: - . Aristophanic poetry. Götingen: Wandehoeck und Ruprecht, 1981, p.18-47.

MURRAY, Gilbert. The plays of escape (Birds). In: - . Aristophanes: a study. Oxford: Clarendon Press, 1933, p.135-163.

NEWIGER, Hans. Die Vögel und ihre Stellung im Gesamtwerk des Aristophanes. In: NEWIGER, Hans, org. Aristophanes und die Alte Komödie. Darmstadt: Wissenschaftliche Buchgesellschaft, 1975, p.266-292.

POLLARD, John. Birds in the greek life and myth. London: Faber \& Faber, 1977.

RECKFORD, Kenneth. Aristophanes old-and-new comedy (v:1, Six essays in perspective). Chapel Hill: University of North Carolina, 1987.

RODRIGUES, Antonio Medina. Mito e utopia em As Aves de Aristófanes. In: CARDOSO, Zélia, org. Mito, religiāo e sociedade (Atas do II Congresso Nacional de Estudos Clássicos). São Paulo: SBEC, 1991, p.50-56.

RUCK, Carl. Hongos y filósofos. In: WASSON, Gordon, org. La Búsqueda de Pérsefone (Los enteógenos y los origenes de la religión). México: Fondo de Cultura Económica, 1992, p.189-226.

TAILLARDAT, Jean. Les images d'Aristophane. Paris: Les Belles Lettres, 1965. 
THIERÇY, Pascal. Aristophane: fiction et dramaturgie. Paris: Les Belles Lettres, 1986:

WHITMAN, Cedric. Aristophanes and the comic hero. Cambridge/Massachusetts: Harvard University Press, 1964.

DUARTE, A. da Silva. La plus grande des merveilles. Classica, São Paulo, 5/6: 97-110, 1992/1993.

RESUME: L'étude des dernières strophes lyriques des Oiseaux est le point de départ qui permet d'examiner le rôle de l'imagination dans la poésie d'Aristophane et aussi d'interpréter cette comédie comme une critique d'Athènes et des athèniens (elle n'est pas une comédie d'évasion, comme veut Murray).

MOTS CLÉS: Aristophanes, comédie attique antique, théâtre, grotesque. 